\title{
Bioassay for detection of transgenic soybean seeds tolerant to glyphosate ${ }^{(1)}$
}

\author{
Antonio Carlos Torres ${ }^{(2)}$, Warley Marco Nascimento ${ }^{(2)}$, Sonia Alessandra Vasconcelos Paiva(2) \\ and Fernando Antonio Souza de Aragão(2)
}

\begin{abstract}
Glyphosate is a systemic, nonselective, postemergence herbicide that inhibits growth of both weeds and crop plants. Once inside the plant, glyphosate interferes with biosynthesis of aromatic amino acids phenylalanine, tyrosine, and tryptophan, by inhibiting the activity of 5-enolpyruvylshikimate-3-phosphate synthase (EPSPS), a key enzyme of the shikimate pathway. The objective of this work was to develop a simple, effective and inexpensible method for identification of transgenic soybean tolerant to glyphosate. This technique consisted in germinating soybean seeds in filter paper moistened with 100 to $200 \mu \mathrm{M}$ of glyphosate. Transgenic soybean seeds tolerant to glyphosate germinated normally in this solution and, between 7 and 10 days, started to develop a primary root system. However non-transgenic seeds stopped primary root growth and emission of secondary roots.
\end{abstract}

Index terms: Glycine max, herbicide resistance, transgenic plants, biosynthesis.

Bioensaio para detecção de sementes de soja transgênicas tolerantes ao glifosato

\begin{abstract}
Resumo - Glifosato é um herbicida sistêmico, não seletivo, aplicado em pós-emergência que inibe o crescimento de plantas daninhas e cultivadas. Uma vez na planta esse herbicida interfere com a biossíntese de aminoácidos aromáticos (fenilalanina, tirosina e triptofano) mediante inibição da atividade da enzima 5-enolpiruvilshiquimato-3-fosfato sintase (EPSPS), enzima-chave na rota do shiquimato. O objetivo deste trabalho foi desenvolver um método simples, barato e efetivo para o rastreamento de soja transgênica com tolerância ao glifosato. Este sistema consistiu em usar papel de filtro umedecido com solução de 100 a $200 \mu \mathrm{M}$ do herbicida glifosato como substrato de germinação de sementes de soja. Sementes transgênicas de soja tolerantes ao glifosato germinaram normalmente nessa solução e, entre 7 e 10 dias, desenvolveram um sistema radicular normal, enquanto nas sementes de soja não-transgênicas ocorreram paralisações do crescimento da raiz primária e da emissão de raízes secundárias.
\end{abstract}

Termos para indexação: Glycine max, resistência a herbicida, plantas transgênicas, biossíntese.

\section{Introduction}

The global market for agricultural products and agricultural-based value-added products is undergoing change as the top players in agriculture and agriculture biotechnology face increased consolidation, production and market (Kolodziejczyk

\footnotetext{
(1)Accepted for publication on July 24, 2003.

(2) Embrapa-Centro Nacional de Pesquisa de Hortaliças, Caixa Postal 218, CEP 70359-970 Brasília, DF, Brazil. E-mail: torres@cnph.embrapa.br,wmn@cnph.embrapa.br, spaiva@cnph.embrapa.br, aragao@cnph.embrapa.br
}

\& Fedec, 1999). Herbicide tolerant soybean has been the most dominant transgenic crop grown commercially in several countries (USA, Argentina, Canada, Mexico, Romania, and Uruguay) (James, 2000). Among herbicide tolerant soybean are those genotype transformed with 5-enolpyruvylshikimate-3-phosphate synthase gene (CP4 EPSPS) from Agrobacterium sp. CP4 which confers tolerance to the herbicide glyphosate. The herbicide glyphosate (Round-up ${ }^{\mathrm{TM}}$ ) was identified for its broad spectrum effectiveness to control weeds. Once inside the plant, glyphosate inhibits the activity of the enzyme 5-enolpyruvylshikimate-3-phosphate synthase (EPSPS). The inhibition of this enzyme 
prevents biosynthesis of aromatic amino acids that are necessary for plant growth (Amrhein et al., 1980; Mousedale \& Coggins, 1984; Wang et al., 1991; Herrmann, 1995; Bradshaw et al., 1997; Franz et al., 1997; John, 1997).

In general, GMO (Genetically Modified Organism) identification tests are performed by DNA analysis (PCR test and Southern blot analysis) or by immunological detection of protein (ELISA test and Western blot analysis).

All procedures are not easily adapted to be used in routine seed testing laboratory.

The objective of this work was to describe an effective, simple and inexpensive biotest for visual detection of transgenic soybean seedlings tolerant to glyphosate.

\section{Material and Methods}

Glycine $\max$ L. cv. BR16 (non-transgenic) and the correspondent transgenic cultivar BR99 seeds were disinfested in $0.5 \%$ sodium hypochlorite solution, for 20 minutes. Following disinfestation, the seeds were rinsed three times, with autoclaved distilled water and germinated in germination paper moistened in solution containing 0 , 50,100 and $200 \mu \mathrm{M}$ of glyphosate. The germination paper was wrapped and placed in vertical position in $2,000 \mathrm{~mL}$ beaker and incubated in germination chamber at $25^{\circ} \mathrm{C}$ in the dark. The experimental setup was a random complete block design in a factorial $4 \times 2$ with four levels of glyphosate $(0,50,100$ and $200 \mu \mathrm{M})$ combined with two genotypes (transgenic and non-transgenic) with four replications. Each replication consisted of 50 seeds. Germination and root growth were evaluated at 13 days, by measurements of taproot length, number of secondary root formed, fresh and dry mass of roots. Roots were dried for 72 hours at $70^{\circ} \mathrm{C}$. Regression analysis was obtained to evaluate morphological response of transgenic and non-transgenic soybean at different concentration of glyphosate. For each trait, with statistical significance, a graphic containing theoretical curves to transgenic and non-transgenic genotypes was constructed. Contrast (t test) was performed to compare transgenic and non-transgenic seedlings by different regression parameters.

\section{Results and Discussion}

In transgenic genotype the regression analysis between growth characteristics and increasing glyphosate concentrations $(0,50,100$ and $200 \mu \mathrm{M})$ was not significant for germination, taproot length and root dry mass. Whereas, a significant effect for number of secondary roots and root fresh mass was observed. In non-transgenic genotype, the regression analysis was significant for all traits, except for germination (Table 1).

The contrast showed no difference between transgenic and non-transgenic regarding intercept parameter (point without glyphosate dosage) (Table 2). In the absence of glyphosate, growth characteristics including seed germination, taproot length, number of secondary root, fresh and dry mass did not present significant differences between transgenic and non-transgenic genotypes. This fact indicated that transformation did not affect seedling growth at the control treatment. Similar results were disclosed in several reports of transgenic plants tolerant to glyphosate (Padgette et al., 1995; Mannerlöf et al., 1997; Torres et al., 1999; Nagata et al., 2000). In relation to regression (angular) coefficient, the contrasts presented differences between genotypes for all characteristics evaluated, except for germination (Table 2).

Germination in both genotypes was not affected by glyphosate concentration, up to $200 \mu \mathrm{M}$ (Figure 1). The percent of seed germination of transgenic and non-transgenic genotypes in relation to increasing

Table 1. Values from analysis of variance for testing regression significance between transgenic and non-transgenic soybean genotypes ${ }^{(1)}$.

\begin{tabular}{lccccc}
\hline Genotype & GER & TRL & NSR & RFM & RDM \\
\hline Transgenic & 0.32 & 0.11 & 0.02 & $<0.01$ & 0.21 \\
Non-transgenic & 0.63 & $<0.01$ & $<0.01$ & $<0.01$ & $<0.01$ \\
\hline
\end{tabular}

(1)Based in a linear regression model: $\mathrm{y}=\mathrm{a}+\mathrm{bx}$; GER: germination; TRL: taproot length; NSR: number of secondary roots; RFM: root fresh matter mass; RDM: root dry matter mass.

Table 2. Probability values from contrast performed between transgenic and non-transgenic for each angular and linear coefficients, which were estimated by the regression analysis ${ }^{(1)}$.

\begin{tabular}{lccccc}
\hline Coefficient & GER & TRL & NSR & RFM & RDM \\
\hline Intercept (a) & 0.35 & 0.55 & 0.15 & 0.62 & 0.29 \\
Regression (b) & 0.87 & $<0.01$ & $<0.01$ & $<0.01$ & $<0.01$ \\
\hline
\end{tabular}

${ }^{(1)}$ Based in a linear regression model: $y=a+b x$; GER: germination; TRL: taproot length; NSR: number of secondary roots; RFM: root fresh matter mass; RDM: root dry matter mass. 
glyphosate concentration showed no statistical differences. This parameter was measured by contrast between angular coefficients (Table 2). Probably glyphosate absorption and translocation did not proceed at the same rate as observed in many studies (Franz et al., 1997). Also, the embryo may have a limited inherent capacity for absorption of glyphosate or the concentration tested was not enough to kill the embryo in the early stage of development. This suggests that germination is not a good characteristic to be used for screening among transgenic and non-transgenic soybean using up to $200 \mu \mathrm{M}$ of glyphosate. However, in transgenic rice (resistant to ammonium-glufosinate), viability by tetrazolium test has been proposed to identify transgenic and non-transgenic genotype using high concentration of the herbicide (100 M) (Ayala et al., 2002).

Root growth was evaluated by measurements of taproot length, number of secondary roots formed, and by fresh and dry matter mass. Eshel \& Waisel (1996) also employed these variables to estimate root development in a given substrate. The contrast performed between transgenic and non-transgenic (Table 2) showed significance for taproot length in relation to angular coefficient. Non-transgenic seedlings presented a linear negative effect with the increase of the glyphosate concentration (Figure 2). In general, the higher glyphosate concentration, the shorter root growth. In transgenic genotypes, the growth extension of primary roots was not affected by the addition of glyphosate up to $200 \mu \mathrm{M}$. To establish a bioassay, it is important that the transgenic and non-transgenic seedlings have a clear morphological characteristic that could be used for screening both genotypes (Torres et al., 1999). In this study, transgenic seedlings exposed to glyphosate produced main root that elongated faster and more continuously than those of non-transgenic (Figures 2 and 3). This visual characteristic associated with statistical analysis indicates that root elongation could be used as an accurate prediction for screening both soybean genotypes in early stage of development.

The number of secondary root formed per plant decreased significantly with the increasing of glyphosate concentration in transgenic and non-transgenic seedlings (Table 1 and Figure 4). The number of secondary roots showed distinct inverse linear response for both genotypes in relation to glyphosate (Figure 4). Thus, the number of secondary roots was not an adequate parameter to be used for screening. Also, under glyphosate conditions extension growth of secondary roots was inhibited in non-transgenic soybean, with formation of rudimentary roots along the main axis (Figure 3 ). However, transgenic seedlings had normal secondary root elongation.

Similarly, there was a significant linear negative effect of genotype and glyphosate for mass of root fresh matter. The mass of root fresh matter decreased with increasing glyphosate concentration from 0 to $200 \mu \mathrm{M}$ and the regression variance analysis was significant for both genotypes (Figure 5). The

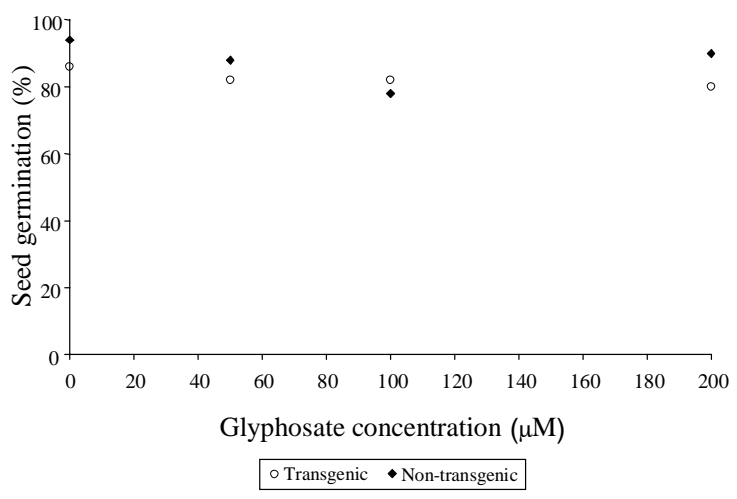

Figure 1. Average of percent of seed germination of transgenic and non-transgenic genotypes in relation to the increase of glyphosate concentration up to $200 \mu \mathrm{M}$.

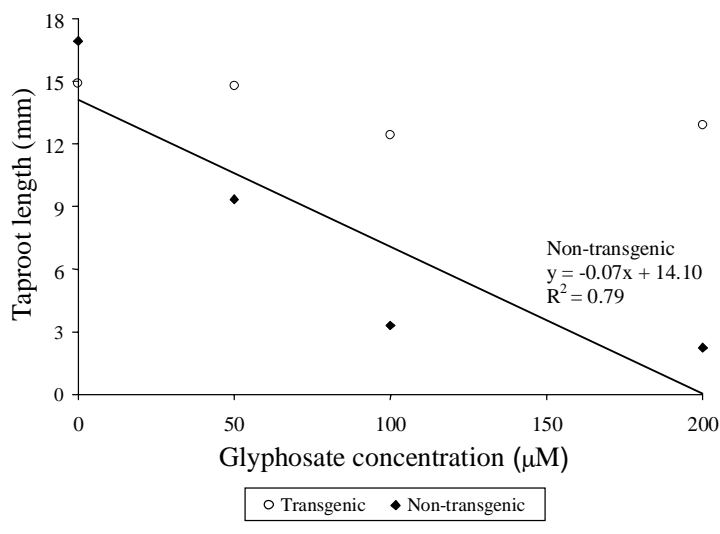

Figure 2. Average of taproot length (TRL) (mm) of transgenic genotype and adjusted regression curves for TRL of non-transgenic genotype in relation to the increase of glyphosate concentration up to $200 \mu \mathrm{M}$. 


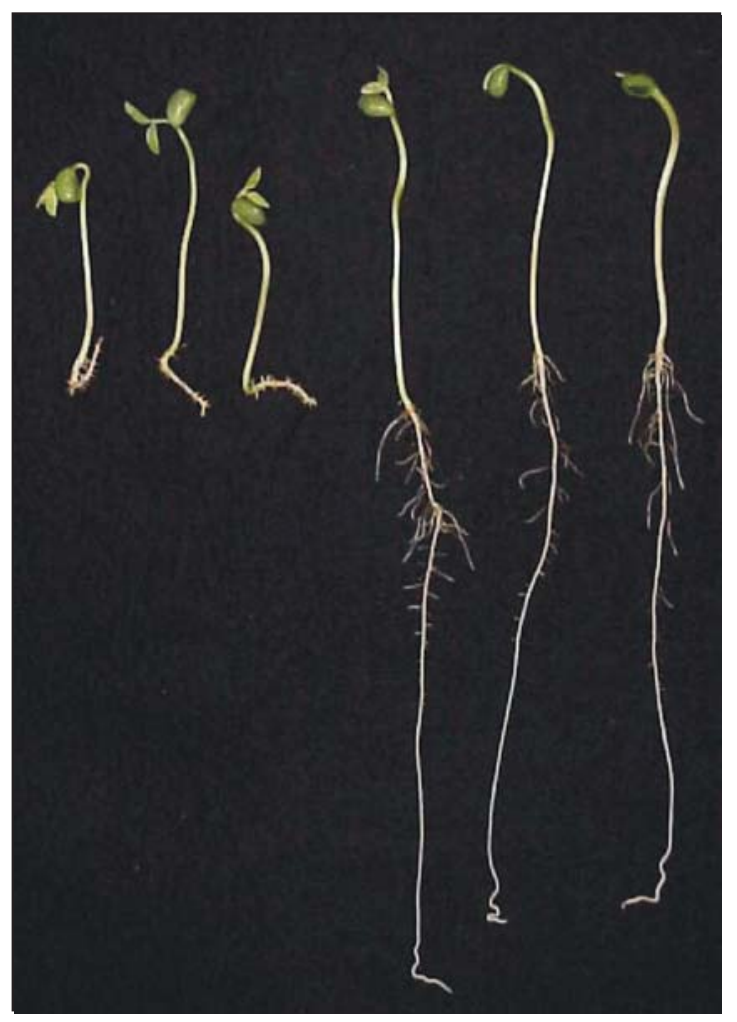

Figure 3. Non-transgenic (left) and transgenic (right) soybean seedlings growing in medium with $200 \mu \mathrm{M}$ of glyphosate.

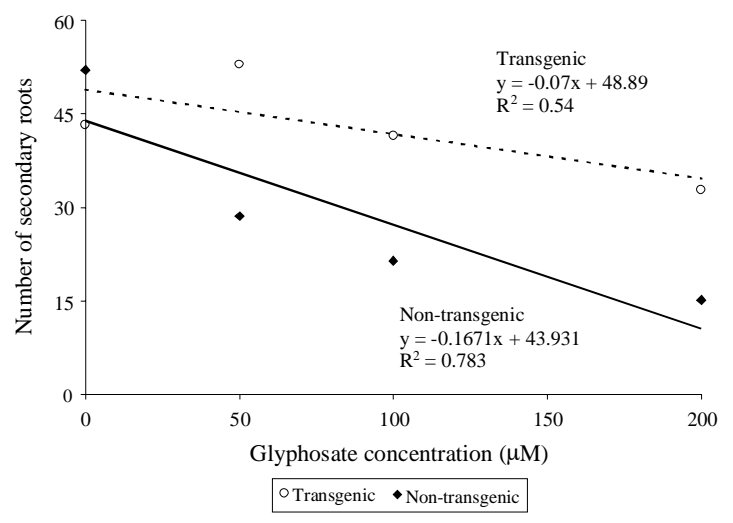

Figure 4. The adjusted regression curves for number of secondary roots of transgenic and non-transgenic genotypes in relation to the increase of glyphosate concentration up to $200 \mu \mathrm{M}$. inhibition of fresh root matter was more intensified in non-transgenic than in transgenic plants (Table 2). Therefore, this characteristic was not a good parameter for distinction between transgenic and non-transgenic seedlings.

Only in transgenic seedlings, the mass of root dry matter was not affected by addition of glyphosate (Figure 6) and the contrast between angular coefficient of regression for genotypes (Table 2) was highly significant. This result showed that root dry matter mass also could be used to separate both genotypes under glyphosate exposition. However this parameter can be influenced by seed physiological quality.

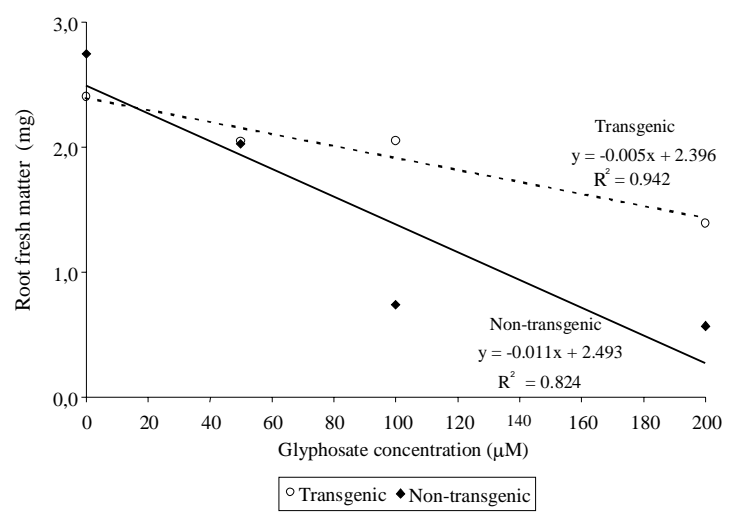

Figure 5. The adjusted regression curves for root fresh matter of transgenic and non-transgenic genotypes in relation to the increase of glyphosate concentration up to $200 \mu \mathrm{M}$.

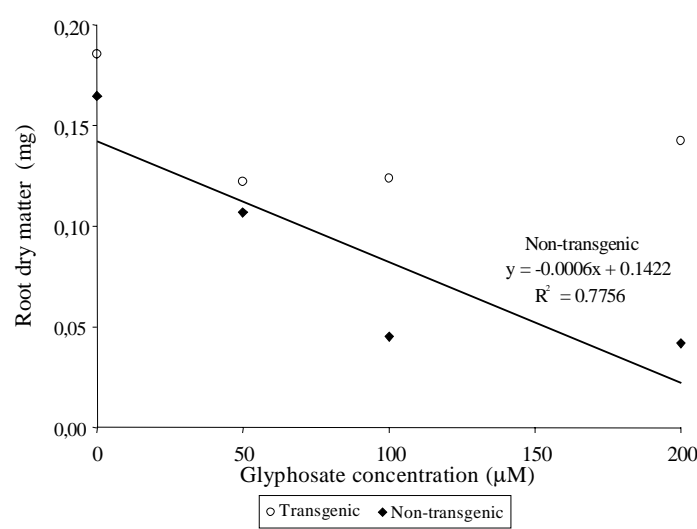

Figure 6. The adjusted regression curves for root dry matter of transgenic and non transgenic genotypes in relation to the increase of glyphosate concentration up to $200 \mu \mathrm{M}$. 


\section{Conclusion}

Taproot length is the best characteristic for identification of transgenic and non-transgenic soybean genotypes when seedlings are grown in germination paper moistened in glyphosate solution up to $200 \mu \mathrm{M}$.

\section{References}

AMRHEIN, N.; DEUS, B.; GEHRKE, P.; STEINRÜCKEN, H. C. The site of inhibition of the shikimate pathway by glyphosate. Plant Physiology, Rockville, v. 65, p. 830-834, 1980.

AYALA, L.; TILLMAN, M. A. A.; DODE, L. B.; VILLELA, F. A. Tetrazolium test for identification of transgenic rice seeds tolerant to herbicide. Seed Science \& Technology, Zurich, v. 30, p. 431-436, 2002.

BRADSHAW, L. D.; PADGETTE, S. R.; KIMBALL, S. L.; WELLS, B. H. Perspectives on glyphosate resistance. Weed Technology, Champaign, v. 11, p. 189-198, 1997.

ESHEL, A.; WAISEL, Y. Multiform and multifunction of various constituents of one root system. In: WAISEL, Y; ESHEL, A.; KAFKAFI, U. (Ed.). Plant roots: the hidden half. $2^{\text {nd }}$ ed. New York: M. Dekker, 1996. p. 175-192.

FRANZ, J. E.; MAO, M. K.; SIKORSKI, J. A. Glyphosate: a unique global herbicide. Washington: American Chemical Society, 1997. (Monograph, 189).

HERRMANN, K. M. The shikimate pathway: early steps in the biosynthesis of aromatic compounds. Plant Cell, Rockville, v. 7, p. 907-919, 1995.

JAMES, C. Global review of commercialization of transgenic crops: 2000. ISAA Briefs, Ithaca, v. 21, p. $1-15,2000$.
JOHN, M. E. Cotton crop improvement through genetic engineering. Critical Reviews in Biotechnology, Boca Raton, v. 17, p. 185-208, 1997.

KOLODZIEJCZYK, P. P.; FEDEC, P. Recent progress in agricultural biotechnology and opportunities for contract research and development. In: SHAHID, F.; KOLODZIEJCZYK, P.; WHITAKER, J. R.; MUNGUIA, A. L.; FULLER, G. (Ed.). Chemical via higher plant bioengineering. New York: Kluwer, 1999. p. 5-20.

MANNERLÖF, M.; TUVESSON, S.; STEEN, P.; TENNING, P. Transgenic sugar beet tolerant to glyphosate. Euphytica, Wageningen, v. 94, p. 83-91, 1997.

MOUSEDALE, D. M.; COGGINS, J. R. Purification and properties of 5-enolpyruvylshikimate-3-phosphate synthase from seedlings of Pisum sativum L. Planta, New York, v. 160, p. 78-83, 1984.

NAGATA, R. T.; DUSKY, J. A.; FERL, R. J.; TORRES, A. C.; CANTLIFFE, D. J. Evaluation of glyphosate resistance in transgenic lettuce. Journal of the American Society for Horticultural Science, Alexandria, v. 125, p. 669-672, 2000 .

PADGETTE, S. R.; KOLACZ, K. H.; DELANNAY, X.; RE, D. B.; LA VALLEE, B. J. Development, identification, and characterization of a glyphosate tolerant soybean line. Crop Science, Madison, v. 35, p. 1451-1461, 1995.

TORRES, A. C.; NAGATA, R. T.; FERL, R. J.; BEWICK, T. A.; CANTLIFFE, D. J. In vitro assay selection of glyphosate resistance in lettuce. Journal of the American Society for Horticultural Science, Alexandria, v. 124, p. 86-89, 1999.

WANG, Y.; JONES, J. D.; WELLER, S. C.; GOLDSBROUGH, P. B. Expression and stability of amplified genes encoding 5-enolpyruvylshikimate-3phosphate synthase in glyphosate tolerant tobacco cells. Plant Molecular Biology, Dordrecht, v. 17, p. 1127-1138, 1991. 